\title{
Development of multiple-choice grammaticality judgement tests
}

\author{
AMMA Kazuo \\ Tamagawa University \\ ammallit.tamagawa.ac.jp
}

\section{Introduction}

Traditional grammaticality judgement tests which have been widely used in second language acquisition studies as an index of language growth and explicit or implicit errors in the interlanguage are flawed in terms of the test reliability. The source of the problem lies in the structure of the test format: dichotomous yes-no questions. As a result, (1) the responses comprise a high risk of chance-level errors, and (2) no informative feedback of errors can be provided to the test-takers.

The purpose of this research is to investigate the appropriateness of multiple-choice test type for grammaticality judgements. We aim to increase the test reliability while retaining the content validity of test items. In other words our goal is to find an equilibrium point between psychometric accuracy and psychological adequacy.

\section{Background studies}

\subsection{Grammaticality judgement tests}

There have been pros and cons as to the validity of grammaticality judgement tests. On the one hand, those who focused on the concurrent validity tended to agree that grammaticality judgement is both a reliable and a stable measure. Hsia (1993) reported a high correlation between pairs of grammaticality judgement, paraphrasing, and reading comprehension among ESL speakers of mixed L1 background except for Cantonese speakers for whom grammaticality judgement and paraphrasing did not correlate with reading comprehension. Similarly, Leow (1996) came up with a high correlation with oral production test in Spanish as a second language. Ito (1997, 1998) confirmed high reliability and moderate validity of grammaticality judgement. According to him a high correlation between each pair of cloze, grammaticality judgement, and sentence combining tasks suggested that grammaticality judgement was an effective means of measuring test takers' linguistic/metalinguistic knowledge. Han \& Ellis (1998) administered two kinds of tests: (1) a timed test for measuring implicit knowledge, including timed grammatical judgement and timed oral production, and (2) a delayed test for measuring explicit knowledge, including a delayed grammatical judgement test and an oral interview for metalinguistic knowledge. Both (1) and (2) correlated with Secondary Level English Proficiency Test, but only (2) correlated with TOEFL. (Cf. Sorace's (1990) criticism on the use of metalinguistic knowledge.)

On the other hand, people who examined the content and construct validity were on the whole of negative opinions. Yoshitake (1991) concluded that although grammaticality judgement was a stable reliable measure of Japanese ESL learners' interlanguage, some items showed indeterminacy. Similarly, Gass (1994) remarked that the reliability of grammaticality judgement was inseparable from the indeterminacy of responses. Gass (1994: 305) contended that whereas the judgement in the primary language was to question the fixed language system, that in the 
second language included indefiniteness or instability, because they were involved in the stage of incomplete learning. "... inferences are being made not about the system they are being asked about, but about some internalized system." In Ellis (1991) Chinese learners of English showed inconsistency in $22.5 \%$ of the responses. Therefore, according to Ellis, cautions must be taken when using grammaticality judgement. (Note that there were too few subjects; $\mathrm{n}=21$ for the first experiment, and $\mathrm{n}=8$ for the second experiment.) Johnson, et al (1996), using grammaticality judgement test against Chinese speakers of ESL, indicated that L2 learners were qualitatively and quantitatively different from L1 speakers. In addition, L2 learners tended to answer "yes" to grammaticality judgements. Furthermore, Hyltenstam (1982), Gass \& Selinker (1994: 35-36) and Sorace (1990) doubted if grammaticality judgement was a genuine elicitation procedure. Hyltenstam (1982), in an attempt to investigate the variability of several elicitation measures, found that grammaticality judgement alone showed a disorderly pattern, elusive of the NP Accessibility Hierarchy defined by Keenan \& Comrie (1977). Sorace (1990: 140-141) pointed out that the dichotomous nature in grammaticality judgement was incompatible with the accreditive nature of the learner's interlanguage status:

"Let us consider the case in which a learner is asked to produce an absolute judgement ("correct" vs. "incorrect") on a construction that is not yet - or no longer - determinate in his/her interlanguage grammar. Any sentence exemplifying that construction will be marked as either correct or incorrect without having such a status in the interlanguage grammar: the learner's choice will be random. If there are different versions of the same test sentence, judgements may or may not be inconsistent. If they are not, the researcher is left with the deceptive impression that the construction is determinate. But if judgements are inconsistent, there can be no unambiguous interpretation of such inconsistency. ... The validity of judgements obtained through dichotomous judgements is therefore highly questionable."

The sources of the problems raised by the literature mentioned above can be sorted into two categories: (1) conversion of the indeterminate nature of interlanguage into a dichotomous form as "correct" vs. "incorrect", and (2) potential errors inherent to the test type which causes incongruence with other tests. In this research we are exclusively concerned with the latter issue, and intend to minimise the procedural errors.

\subsection{Multiple-choice test format}

In this research I shall investigate the validity of a new test format: multiple-choice grammaticality judgement.

The most obvious disadvantage of conventional grammaticality judgement tests is the high level of error by chance. If someone is asked to say "correct" or "incorrect" against a stimulus sentence, they are likely to respond in such a way that it does not correctly represent their interlanguage status, especially when the interlanguage is indeterminate. Thus they may misinterpret a stimulus sentence and judge it as incorrect when the incorrectness of the sentence derives from some other grammatical features. Alternatively, one may choose the "correct" response while they are not fully aware of the grammar in question. 
One possible solution to this problem is to ask the subjects to identify and correct the errors in the stimulus sentence, as Gass \& Selinker (1994) suggested. However, this method requires some additional cautions.

(1) It tends to overestimate the judgement made against a correct item as correct. Some subjects especially at a low proficiency level would be unable to judge or at best loathe to describe the judgement explicitly. Thus they are more likely to regard it as correct than what their "true" intuition does.

(2) It tends to underestimate the judgement made against an incorrect item as incorrect. This correct judgement assumes that the subject has detected the error and corrected it correctly. Therefore it involves identification + description as well as judgement (cf. Johnson, et al., 1996).

We propose here a multiple-choice format which contains four options on the "correct" side and another four on the "incorrect" side. Subjects were asked to choose a true interpretation/entailment of the stimulus sentence if they judged it as correct. This extra task was to balance the load between "correct" choices and "incorrect" choices. Conversely, they were asked to choose the option which indicated the locus of correction if they judged the stimulus as incorrect. In this research this revised format of grammaticality judgement, consisting of 14 items, was trialed against 156 Japanese college-level EFL learners. It was expected that the revised test format would (1) contribute to the stability or internal consistency and (2) provide information of errors for test-takers on the basis of a logistic regression analysis.

\section{Research \\ Hypothesis}

A multiple-choice format provides improved reliability and validity in comparison with a dichotomous format for grammaticality judgement tests.

\section{Research procedure}

Subjects

Japanese university students of EFL $(n=156)$. They took the dichotomous format test approximately three months after taking the main multiple-choice (MC) format test. Nearly half of them used the version without Japanese translation/interpretation $(n=80)$. Another half used the version with Japanese translation/interpretation $(n=76)$. Additionally, the same $M C$ format test with more items $(i=38)$ was given to a wider range of subjects $(n=1153)$ in an extended research framework. Though this test was separate from our current study the data are shown for reference - as partial confirmation of our prediction under an improved administration condition.

\section{Materials}

(A) $<G J$ test $>$ A multiple-choice grammaticality judgement (GJ) test consisted of 38 error detection $\mathrm{MC}$ items. In each item the stimulus sentence should first be judged as grammatically correct or incorrect. Accordingly, the subjects (Ss) were aked to choose the correct entailment of the stimulus sentence out of four options written in L1, if the sentence was judged as correct; or to choose the one option out of four indicating the locus of error, if the sentence was judged as incorrect.

\section{SAMPLE ITEM:}


(h6) I watched the match because I knew some of the playing people.

正しいと思う場合, この文から吾えることを選んでください.

1. 試合を見たので選手のことがわかるようになった.

2. 選手のことを知っていたら試合はもっとおもしろかっただろうに.

3. 試合を見ても知っている選手のことしか眼中になかった.

4. 少しは選手を知っていたので試合を見た.

[If you think this sentence is correct, choose the correct entailment.

1. I learned more about the players as I watched the match.

2. I could have enjoyed the match if I had known about the players.

3. I only looked at the players I knew during the match.

4. I watched the match because I knew some of the people playing.]

誤りだと思う場合，とこを直せば正しい文になるかを選んでください，下線部分は訂正あ るいは削除すべき埸所を示します。

[If you think this sentence is incorrect, choose the option which indicates which part should be corrected. The underlined parts represent possible locations of errors to be corrected or deleted.]

5. I watched the match because I knew some of the playing people.

6. I watched the match because I knew some of the playing people.

7. I watched the match because I knew some of the playing people.

8. I watched the match because I knew some of the playing people.

(B) <C-test $>$ A C-test was developed by the author and used as an independent measure of the Ss' overall proficiency. It consists of four passages with 122 blanks. See the appendix for details.

\section{Analyses}

(1) Logistic regression analyses

Logistic regression analyses were carried out in order to reveal the distribution of probabilities of options as a continuous function of the overall ability. Where the distribution patterns of the correct option and the collective 'correct' options were different 14 items were selected for the comparison study.

In this study $156 \mathrm{Ss}$ were asked to try the same GJ test again. This time the test format was dichotomous; about half of them $(n=80)$ took Version $A$ where there were only stimulus sentences, the other half $(\mathrm{n}=76)$ took Version $\mathrm{B}$ where the corresponding L1 meaning was provided. Once again a logistic regression analysis was done, in order to compare the distributions of the correct options between the original $\mathrm{MC}$ version and dichotomous version (Versions $\mathrm{A}$ and $\mathrm{B}$ ).

\section{(2) Reliability indices}

To measure the internal consistency of the responses, Kuder Richardson 20 was calculated.

For the MC format two sets of responses were extracted. By 'strict' scoring the subjects were considered to have made a correct judgement who chose the one correct answer out of eight options. By 'collective' scoring they were considered correct as long as they chose one of the four options which belonged to the same category of correct/incorrect judgement as the one correct option. For example, in b3 ("Take this flight which I think that is least expensive"), the correct option is 7. According to the 'strict' scoring the subjects who chose option 7 were considered correct and other subjects who chose the other options were considered incorrect. On the other 
hand, according to the 'collective' scoring the subjects who chose one of the options from 5 to 8 were considered correct and others who chose one of the options from 1 to 4 were considered incorrect. Thus 'strict' scoring is intended to exclude indeterminate responses, while 'collective' scoring is intended to simulate the response pattern created by the dichotomous format.

a. KR 20 of the reference test in the $\mathbf{M C}$ format $(n=1153, \mathrm{i}=38)$

b. KR 20 for the current test in the MC format after 'strict' scoring ( $n=156, i=14)$

c. KR 20 for the current test in the MC format after 'collective' scoring $(n=156, i=14)$

d. KR 20 for the current test in the dichotomous format $(n=156, i=14)$

(3) Correlations

To measure the concurrent validity of the variety of formats, Pearson's product moment correlation coefficients were calculated.

(3.1) Results of the reference study

e. Correlation coefficient between the sum scores of the reference test in the MC format and the standardised C-test scores $(n=1153, \mathrm{i}=38)$

f. Correlation coefficient between the sum scores of the reference test in the MC format and the TOEFL scores based on the Ss' self report $(n=183, \mathrm{i}=38)$

(3.2) Effect of the two formats on C-test

g. Correlation coefficient between the sum scores of the dichotomous format and the standardised C-test scores $(n=156, i=14)$

h. Correlation coefficient between the sum scores of the MC format after 'strict' scoring and the standardised C-test scores $(n=156, i=14)$

i. Correlation coefficient between the sum scores of the MC format after 'collective' scoring and the standardised C-test scores $(n=156, i=14)$

(3.3) Effect of the two formats on TOEFL

j. Correlation coefficient between the sum scores of the dichotomous format and the TOEFL scores $(n=26, i=14)$

k. Correlation coefficient between the sum scores of the MC format after 'strict' scoring and the TOEFL scores $(n=26, i=14)$

1. Correlation coefficient between the sum scores of the MC format after 'collective' scoring and the TOEFL scores $(n=26, i=14)$

(3.4) Comparison of the two scoring procedures

$\mathrm{m}$. Correlation coefficient between the sum scores of the dichotomous format and the sum scores of the MC format after 'strict' scoring ( $n=156, i=14)$

n. Correlation coefficient between the sum scores of the dichotomous format and the sum scores of the MC format after 'collective' scoring $(n=156, i=14)$

\section{Results}

(1) Logistic regression analyses 
i. Items where the number of correct judgement is smaller in the MC format than that in the dichotomous format: $\mathbf{a 4}, \mathbf{b 3}, \mathbf{9 7}, \mathbf{h 4}$, and $\mathbf{h 6}$. See Figures $1-2$ for the result for item a4. In the following figures area "o" represents the probability (on the vertical scale) of the correct option at a given ability scale (horizontal) by $\mathrm{C}$-z which represents the $\mathrm{C}$-test score standardised at average $=0$ and $s d=1$. Area " $x$ " represents the probability of the incorrect option(s) at a given ability scale by $\mathrm{C}-\mathrm{z}$.

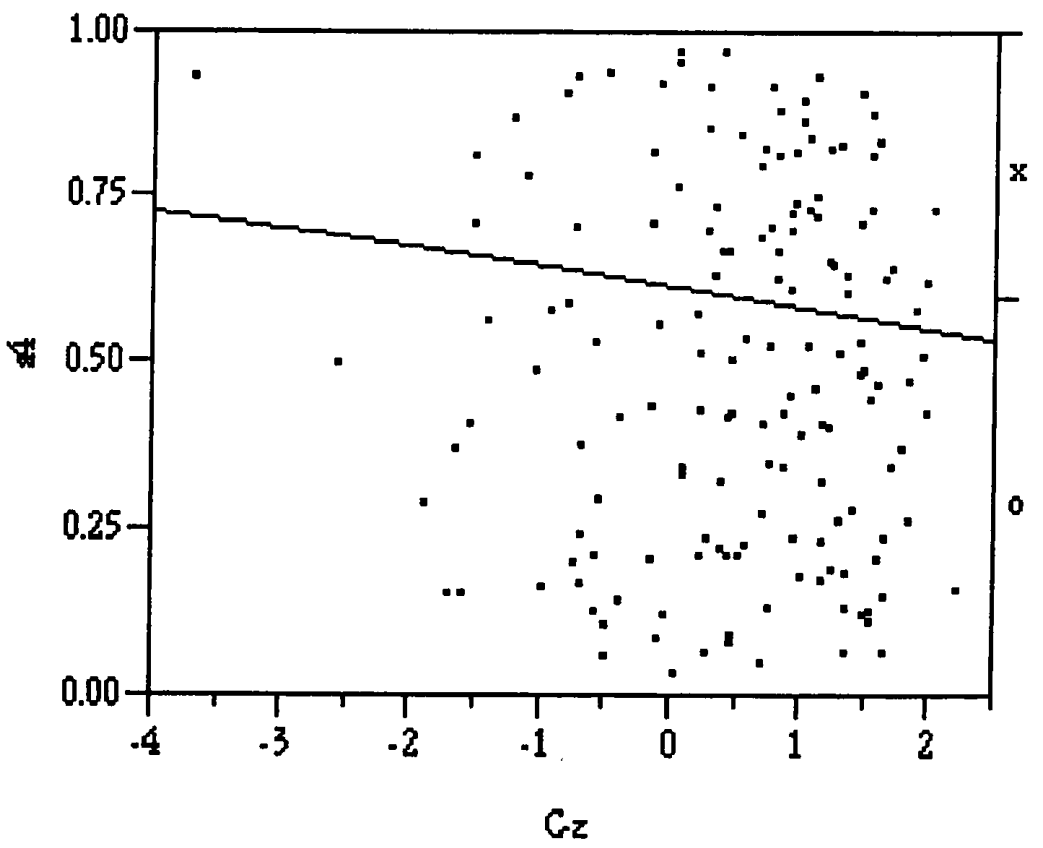

[Figure 1: Logistic regression analysis of $\mathbf{a 4}$ in the dichotomous format test]

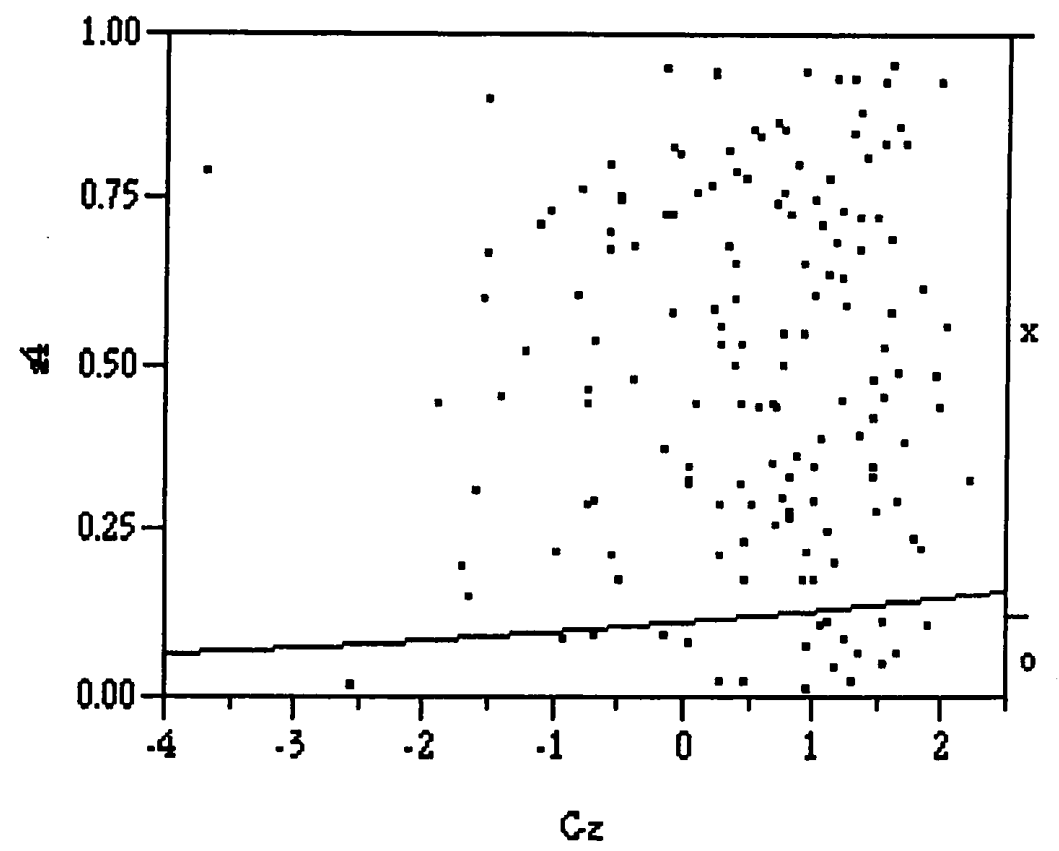

[Figure 2: Logistic regression analysis of $\mathbf{a 4}$ in the multiple-choice format test]

ii. Items where the probability of choosing the correct option becomes closer to the 
chance level for low-proficiency persons in the dichotomous format but smaller in the MC format: a5, d3, g6, and g8. See Figures 3-4 for the result for item $\mathbf{g 6}$.

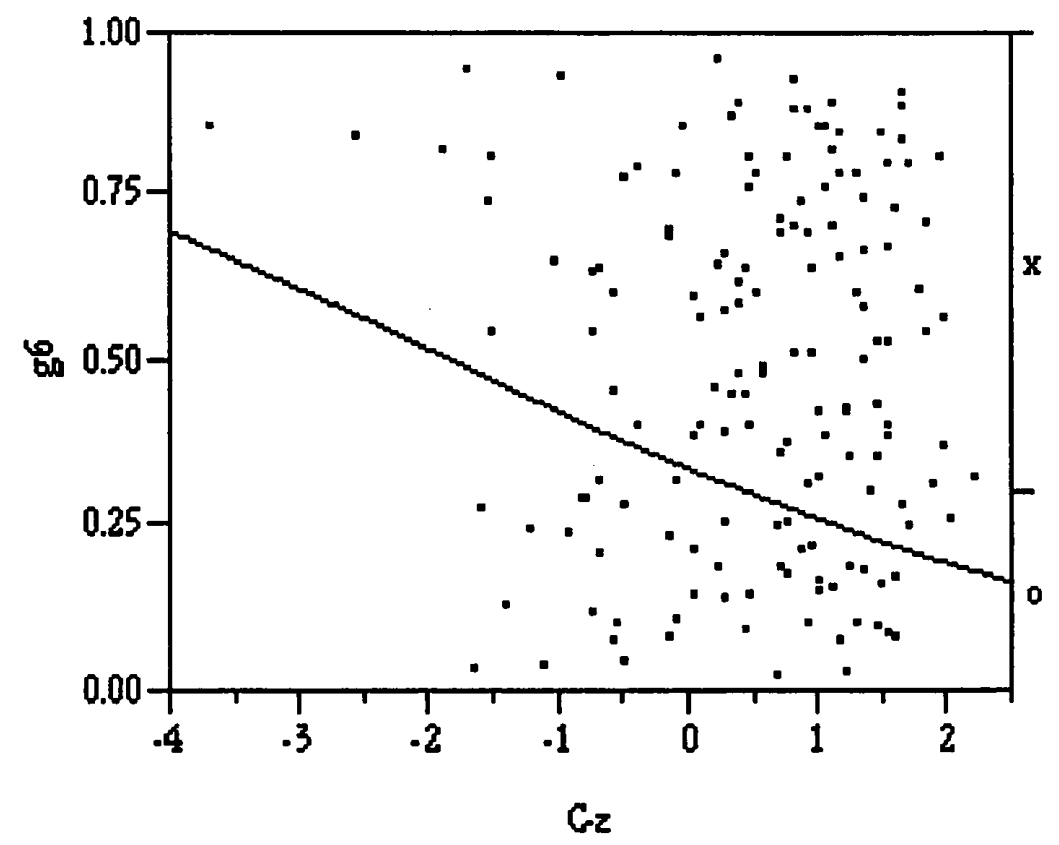

[Figure 3: Logistic regression analysis of 96 in the dichotomous format test]

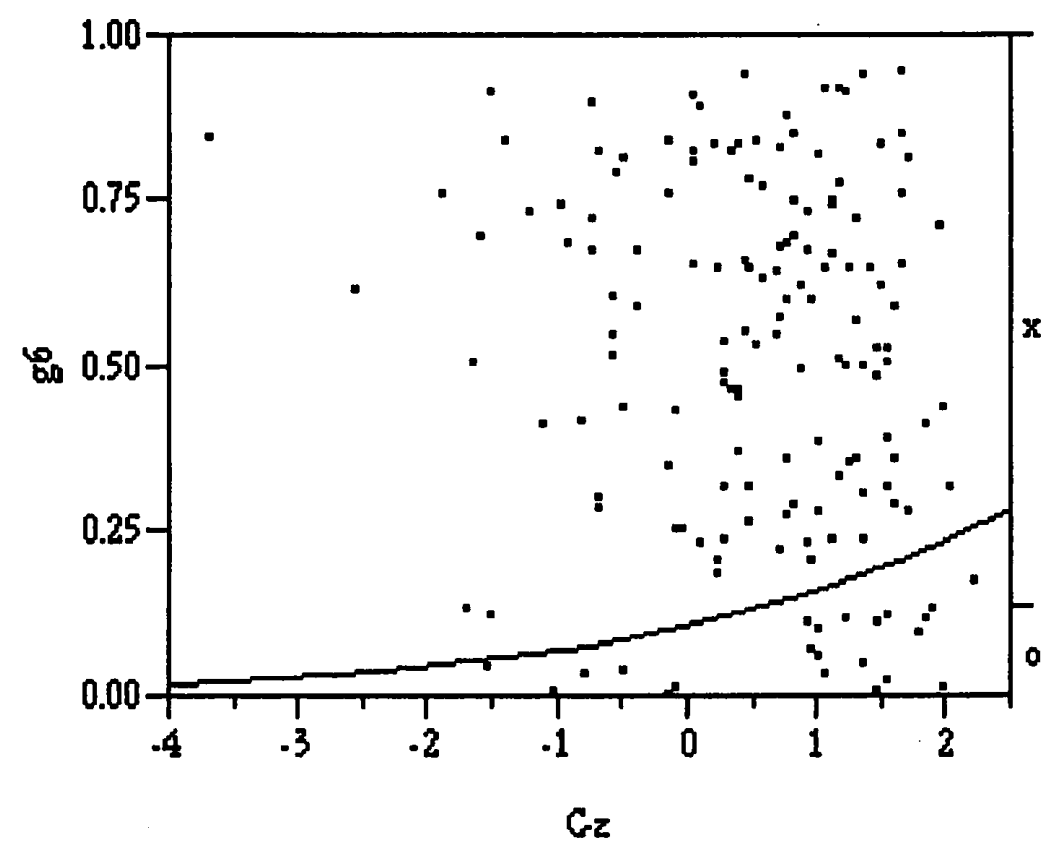

[Figure 4: Logistic regression analysis of 96 in the multiple-choice format test]

iii. Items where the probability of choosing the correct option is even across all ability levels in the dichotomous format but incremental in the MC format: e1. See Figures 5-6 for the result for item $\mathbf{e}$. 


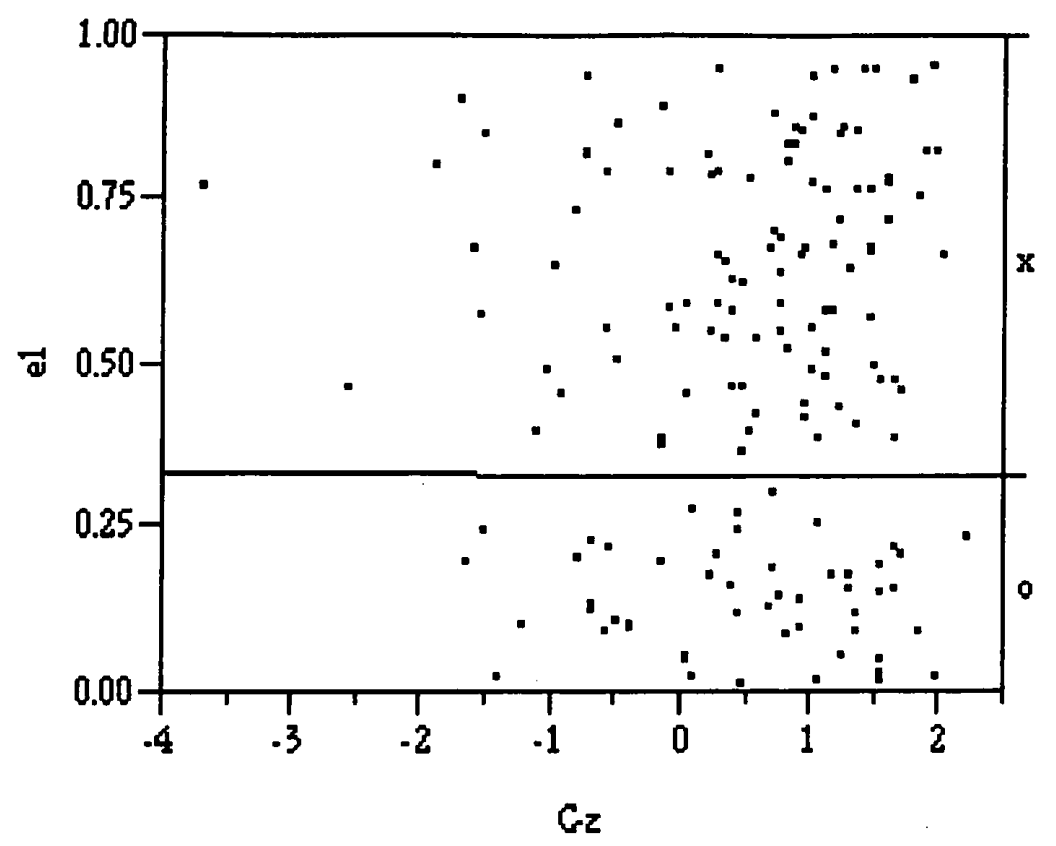

[Figure 5: Logistic regression analysis of $\mathbf{e 1}$ in the dichotomous format test]

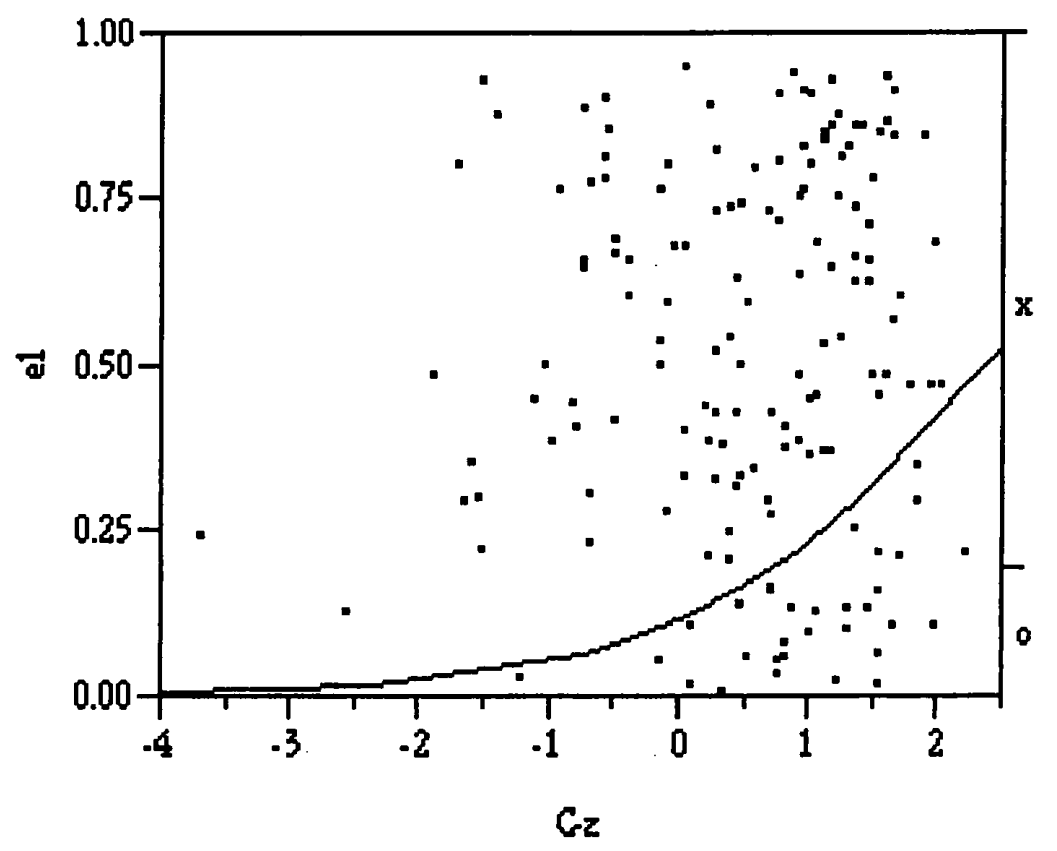

[Figure 6: Logistic regression analysis of $\mathbf{e l}$ in the multiple-choice format test]

iv. Items where the probability distributions of the correct option and the 'collective' correct options are found similar between the dichotomous and MC formats in the sample comparison study (but are distinct in the reference study): b4, b7, c1, and $\mathbf{g 2}$. See Figures 7-9 for the result for item $\mathbf{c} 1$. 


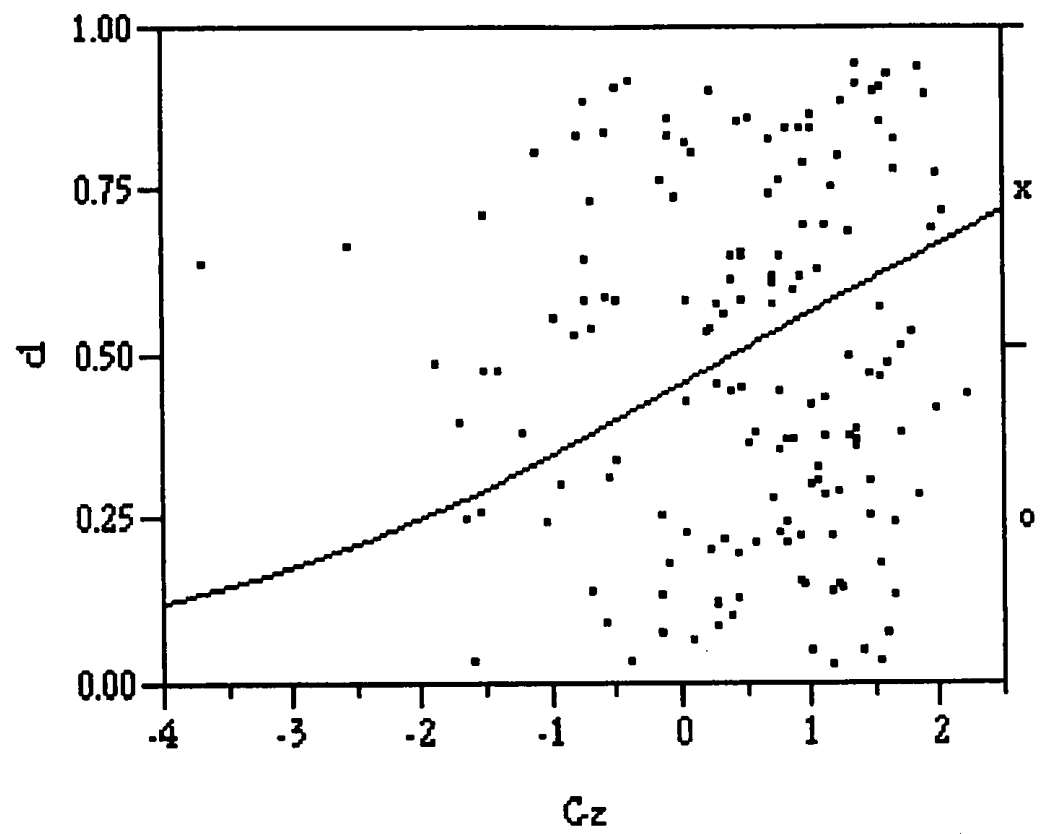

[Figure 7: Logistic regression analysis of $\mathbf{c l}$ in the dichotomous format test]

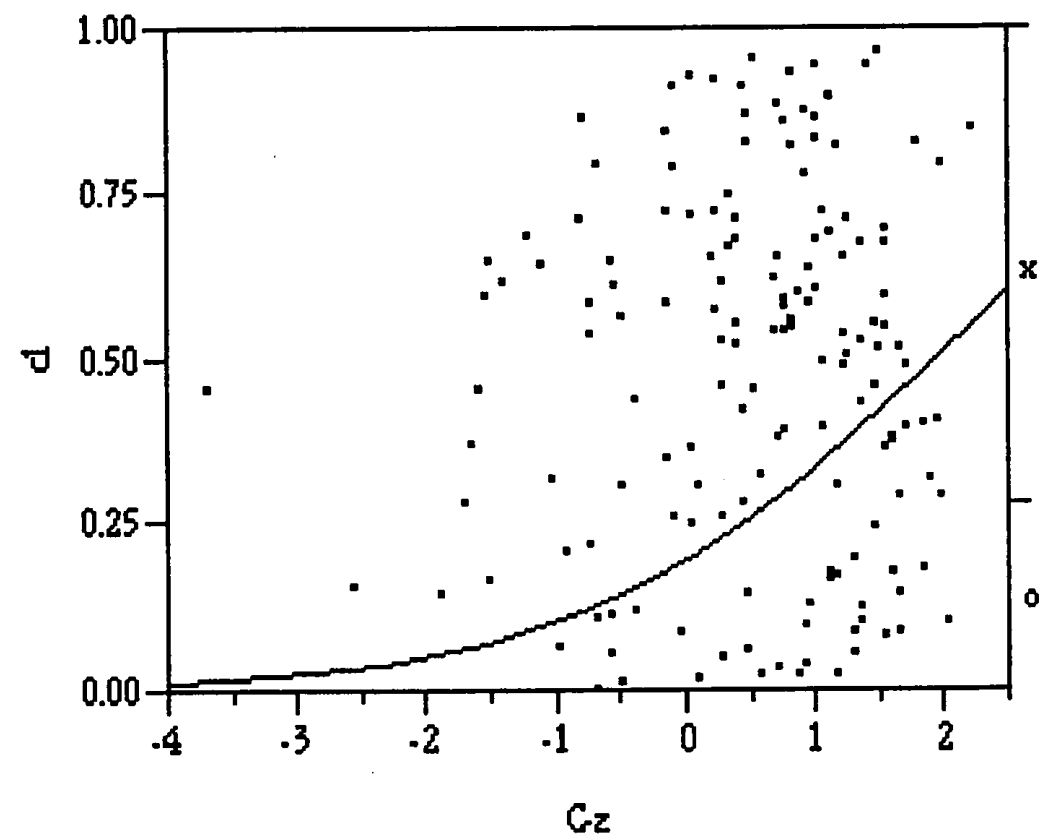

[Figure 8: Logistic regression analysis of $\mathbf{c l}$ in the multiple-choice format test] 


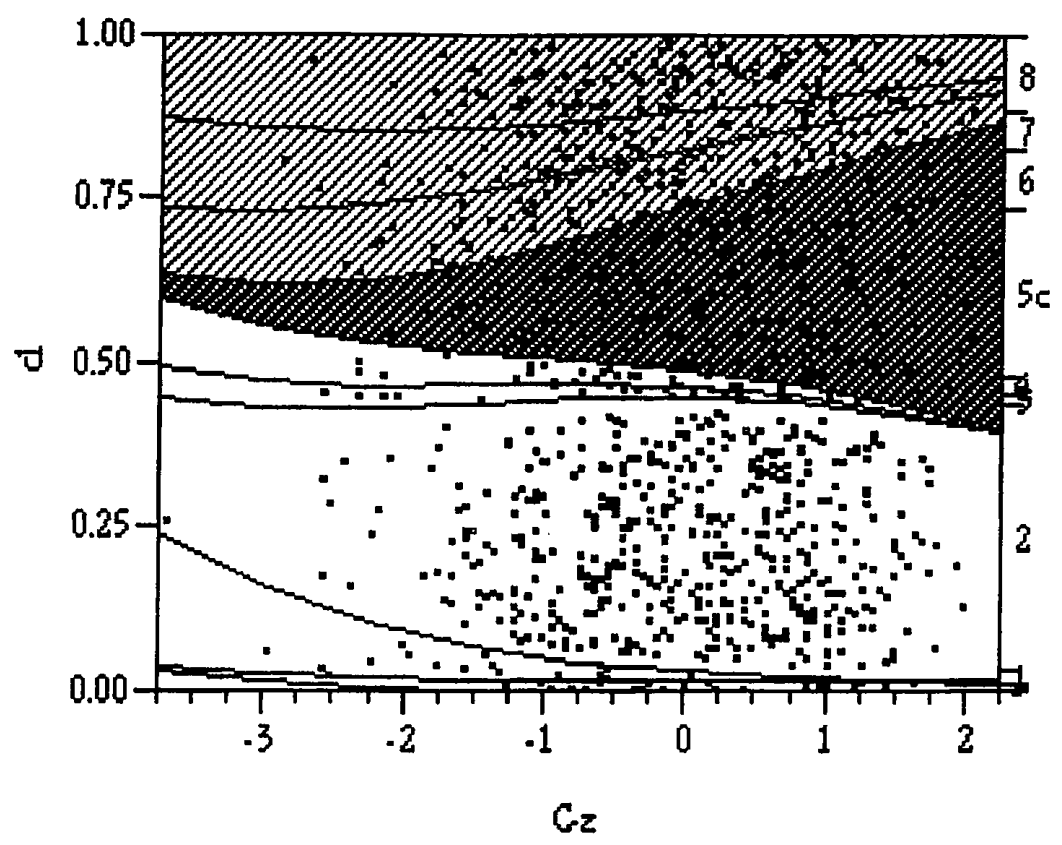

[Figure 9: Logistic regression analysis of $\mathbf{c l}$ in the multiple-choice format of the reference test; $5 c=$ correct option]

(2) Reliability indices

a. For the reference test in the MC format,

$$
r=0.934
$$

$$
(\mathrm{n}=1153, \mathrm{i}=38)
$$

b. For the current test in the MC format corresponding to the comparison study after 'strict' scoring,

$$
r=0.402 \quad(\mathrm{n}=156, \mathrm{i}=14)
$$

c. For the current test in the MC format corresponding to the comparison study after 'collective' scoring,

$$
r=0.559
$$

d. For the current test in the dichotomous format,

$$
\begin{array}{lll}
r=-0.213 & \text { (Versions } \mathrm{A}+\mathrm{B}) & (\mathrm{n}=156, \mathrm{i}=14) \\
r=-0.110 & (\text { Version } \mathrm{A}) & (\mathrm{n}=80, \mathrm{i}=14) \\
r=-0.424 & \text { (Version } \mathrm{B}) & (\mathrm{n}=76, \mathrm{i}=14)
\end{array}
$$$$
(n=156, i=14)
$$

(3) Correlations

(3.1) Results of the reference study

e. The correlation coefficient between the sum scores of the MC format and the standardised C-test scores:

$$
r=0.519 \quad(\mathrm{n}=1153, \mathrm{i}=38, \mathrm{p}<0.001)
$$

f. The correlation coefficient between the sum scores of the MC format and the TOEFL scores based on the Ss' self report:

$$
r=0.545
$$$$
(n=183, \mathrm{i}=38, \mathrm{p}<0.001)
$$ 
(3.2) Effect of the two formats on C-test

g. The correlation coefficient between the sum scores of the dichotomous format and the standardised C-test scores:

$$
\begin{array}{lll}
r=0.141 & \text { (Versions A+B) } & (\mathrm{n}=156, \mathrm{i}=14, \text { n.s. }) \\
r=0.328 & \text { (Version A) } & (\mathrm{n}=80, \mathrm{i}=14, \mathrm{p}<0.01) \\
r=-0.087 & \text { (Version } \mathrm{B}) & (\mathrm{n}=76, \mathrm{i}=14, \text { n.s. })
\end{array}
$$

h. The correlation coefficient between the sum scores of the MC format after 'strict' scoring and the standardised C-test scores:

$$
r=0.406
$$$$
(n=156, i=14, p<0.001)
$$

i. The correlation coefficient between the sum scores of the MC format after 'collective' scoring and the standardised C-test scores:

$$
r=-0.088
$$

$$
(n=156, i=14, \text { n.s. })
$$

(3.3) Effect of the two formats on TOEFL

j. The correlation coefficient between the sum scores of the dichotomous format and the TOEFL scores:

$$
\begin{array}{lll}
r=0.072 & (\text { Versions A+B) } & (\mathrm{n}=26, \mathrm{i}=14, \mathrm{n} . \mathrm{s} .) \\
r=0.339 & \text { (Version A) } & (\mathrm{n}=11, \mathrm{i}=14, \mathrm{n} . \mathrm{s} .) \\
r=-0.065 & (\text { Version } \mathrm{B}) & (\mathrm{n}=15, \mathrm{i}=14, \mathrm{n} . \mathrm{s} .)
\end{array}
$$

k. The correlation coefficient between the sum scores of the MC format after 'strict' scoring and the TOEFL scores:

$$
r=0.332 \quad(\mathrm{n}=26, \mathrm{i}=14, \mathrm{n} . \mathrm{s} .)
$$

1. The correlation coefficient between the sum scores of the MC format corresponding to the comparison study after 'collective' scoring and the TOEFL scores:

$$
r=-0.103
$$$$
(n=26, i=14, \text { n.s. })
$$

(3.4) Comparison of the two scoring methods

$\mathrm{m}$. The correlation coefficient between the sum scores of the dichotomous format and the sum scores of the MC format after 'strict' scoring:

$$
\begin{array}{lll}
r=0.154 & (\text { Versions A+B) } & (\mathrm{n}=156, \mathrm{i}=14, \mathrm{n} . \mathrm{s} .) \\
r=0.241 & \text { (Version A) } & (\mathrm{n}=80, \mathrm{i}=14, \mathrm{p}<0.05) \\
r=0.003 & \text { (Version B) } & (\mathrm{n}=76, \mathrm{i}=14, \text { n.s. })
\end{array}
$$

$\mathrm{n}$. The correlation coefficient between the sum scores of the dichotomous format and the sum scores of the MC format after 'collective' scoring:

$$
\begin{array}{lll}
r=0.122 & (\text { Versions A+B) } & (\mathrm{n}=156, \mathrm{i}=14, \text { n.s. }) \\
r=0.175 & \text { (Version A) } & (\mathrm{n}=80, \mathrm{i}=14, \text { n.s. }) \\
r=0.016 & (\text { Version B) } & (\mathrm{n}=76, \mathrm{i}=14, \text { n.s. })
\end{array}
$$

\section{Discussions}

1. Above all things, the dichotomous and multiple-choice formats represent different constructs. Although some items share similar distribution patterns of the probability of correct options, MC and dichotomous formats present distinct probability patterns (result (1)). This may be due to the 
factor of indeterminacy included in the dichotomous responses.

2. Unlike the reliability coefficient (KR 20) for the MC format, that for the dichotomous format is too low for the test to be practically usable (results $(2 \mathrm{~b})-(2 \mathrm{~d})$ ). This result alone would provide evidence in favour of a MC format. The slightly higher coefficient values for the 'collective' scoring may be due to the increased heterogeneity of scores.

3. As to the concurrent validity with the C-test scores, the $\mathrm{MC}$ format with strict scoring has statistically significant correlation (result (3.2h)), whereas the dichotomous format and the MC format with collective scoring show little or no significance (results $(3.2 \mathrm{~g}),(3.2 \mathrm{i})$ ).

4. As to the concurrent validity with the TOEFL scores, no format/version reached a significance level (result (3.3)). This is due to the small size of the subjects who reported they had taken a TOEFL test, considering the fact that in the reference study which involved a larger number of subjects there was a highly significant correlation between the MC format test scores and TOEFL scores (result (3.1f)).

5. As to the correlation between the $\mathrm{MC}$ and dichotomous formats, only Version $\mathrm{A}$ of the dichotomous format barely reached a significance level of correlation with the $\mathrm{MC}$ format through strict scoring. Other format/scoring methods did not affect the correlation between the two formats (result (3.4)). Again, this result indicates that the two formats are psychometrically distinct.

6. The difference of distribution patterns between the 'collective' correct options in the multiplechoice format and the correct options in the dichotomous format may be due to the different problem-solving processes involved. In the multiple-choice format it was observed by the supervisors that the subjects first read all the options, correct AND incorrect, then chose the option which sounded most convincing. This is the same fallacy that all multiple-choice questions commit. The only way to avoid this problem is to use a computer-based test where the subjects are forced to make a judgement as to correct/incorrect, then are asked to choose why and how in the next page.

\section{Conclusion}

A multiple-choice format is recommended for grammaticality judgement tests. It has a stable reliability and better concurrent validity than a traditional dichotomous format. The major problem, though, is the longer time that the subjects might consume. However, it can be solved by giving a computer-adaptive test. With respect to the basic understanding that the most important point in giving a grammaticality judgement test is to exclude indeterminate factors, the multiple-choice format provides a successful process of narrowing down on 'conviction' responses.

\section{References}

Amma Kazuo. 1997. "Comparison of attractiveness in multiple-choice and dichotomous judgement items." Presentation at the 1st National Conference, JLTA.

Bauer, Hannspeter. 1991. "Sore finger items in mutiple-choice tests." System, 19(4), 453-458. 
Davies, William. \& Tamar I. Kaplan. 1998. "Native speaker vs. L2 learner grammaticality judgements." Applied Linguistics, 19(2), 183-203.

Ellis, Rod. 1991. "Grammaticality judgments and second language acquisition." Studies in Second Language Acquisition, 13(2), 161-186.

Gass, Susan M. 1994. "The reliability of second-language grammaticality judgments." In Elaine E. Tarone, Susan M Gass, \& Andrew D. Cohen (eds.), Research Metbodology in Second-Language Acquisition, 263-286. Hillsdale, NJ: Lawrence Earlbaum Associates.

Hopkins, P. G. E. 1979. "More than one choice in objective testing." English Language Teaching Journal, 34, 221-223.

Imai Takao. 1998. "A reaction to Ito's 'Japanese EFL learners' test-type related interlanguage variability'." JALT Journal, 20(1), 87-88.

Ito Akihiko. 1998. "The author responds: more on test-types." JALT Journal, 20(1), 89-90.

Ito Akihiro. 1997. "Japanese EFL learners' test-type related interlanguage variability." JALT Journal, 19(1), 89-105.

Leow, Ronald P. 1996. "Grammaticality judgment tasks and second-language development." Georgetown University Round Table on Languages and Linguistics, 126-139.

van Susteren, Timothy Joseph. 1997. The comparative reliability and validity of alternate-choice and multiple-choice tests. Ann Arbor: University Microfilms International.

Yoshitake, Sonia Sonoko. 1991. "Grammaticality judgment test as a research instrument." ICU Language Research Bulletin, 6(1), 103-122.

\section{Appendices \\ Grammar test - multiple-choice}

\section{这法挰題}

次の文を砤み，文法的に正しいか誤っているかを判断し，それそれの指示に沿って解答してください、く >には1つ 以上の語が入る可能性があります.また，問題によってはつの文にく>が2ヶ所ある場合もあります.

(Read each sentence. If you think it is grammatically correct, choose the correct interpretation or inference from the original sentence from among options 1 . 4. If you think it is grammatically incorrect, choose the option from among 5.8 which indicates the error to be corrected or deleted (shown by the underline) or some word/phrase to be inserted (at " $<>$ ").

In this list the correct option is indicated by " ". The Japanese instruction is only shown for a4.

(a4) You will find the glasses with red marks on both sides are quite expensive.

正しいと思う埸合，この文から言えることを選んでください，

1. 眼鏡そのものよりあなたか眼鏡を見つけられるかどうかが重要です.

2. 赤い印がついているのであなたは眼鏡を見つけられるでしょう.

3. あなたが眼鏡を見つけると赤い印の価值が上がります。

4. 眼鏡がとても高価であることがわかるでしょう.

喂りたと思う場合、とこを直せば正しい文になるかを選んでください、下線部分は訂正あるいは削除すべき 場所を示し、 < >には何らかの語句が入るものとします.

5. You will find the glasses with red marks on both sides are quite expensive.

6. You will find the glasses with red marks on both sides are quite expensive.

7. You will find the glasses with red marks on both sides $<>$ are quite expensive.

${ }^{\circ} 8$. You will find the glasses with red marks on both sides are quite expensive.

(a5) The Department of Foreign Languages are not located in the new building.

1. 外国語学科は新しい建物にはありませんよ. 
2. 外国語学科の建物は新しくはありません。

3. 新しい学科は外国語学科ではありません.

5. The Department of Foreign Languages are not located in the new building.

4. 外国語学科の新しい建物はここにはありません.

6. The Department of Foreign Languages are not located in the new building.

7. The Department of Foreign Languages are not located in the new building.

8. The Department of Foreign Languages are not located in the new building.

(b3) Take this flight which I think that is least expensive.

1.この飛行機が安いからお乗りなさいよ.

2. 最も安い飛行槽のチケットはすぐに売れてしまう.

3. 安上がりに済ますには飛行柍に乗るのが一番だ.

4. 飛行桡の便は安ければ安いほどよい.

5. Take this flight which I think that is least expensive.

6. Take this flight which I think that is least expensive.

- 7. Take this flight which I think that is least expensive.

8. Take this flight which I think that is least expensive.

(D4) Mr Kawase, vice president of Tomato Bank, he will speak to the press this afternoon.

1. 川瀬氏はトマト銀行副頭取にもかかわらず記者に情報を流すでしょう.

2. トマト銀行副湿取の川瀬氏が午後記者会見をします.

3. 川瀬氏がトマト銀行副頭取になったので，彼（別の人）が午後記者会見をすることになった.

4.トマト银行の副頑取になった川瀬氏はいろいろ発言する榙会が多い。

5. $<>$ Mr Kawase, vice president of Tomato Bank, he will speak to the press this afternoon.

6. $\mathrm{Mr}$ Kawase, $<>$ vice president of Tomato Bank, he will speak to the press this afternoon.

7. Mr Kawase, vice president of Tomato Bank, $<>$ he will speak to the press this afternoon.

- 8. Mr Kawase, vice president of Tomato Bank, he will speak to the press this afternoon.

(b7) I was having such a nice time I didn't want to leave.

・1. とても楽しかったので帰りたくなかった.

2. 私が帰ったらもう楽しみがないことはわかっていた。

3. こんなに楽しいことは今まで経験したことがなかった.

4. 楽しくなかったので早めに鯈った.

5. $<>$ I was having such a nice time I didn't want to leave.

6. I was having such a nice time I didn't want to leave.

7. I was having such a nice time I didn't want to leave.

8. I was having such a nice time $<>$ I didn't want to leave.

(c1) Most people hear "endangered species", they think of animals.

1.人々は「絶隇に穎した種」のことを考えてばかりで動物のことを考えません。

2.「絶滅に類した種」というと動物のことを思い浮かべます.

3. 動物は一般に「絶隇に瀬した種」ではありません。

4. 多くの人にとって「絶隇に傾した種」は絊遠いものです.

- $5 .<>$ most people hear "endangered species", they think of animals.

6. Most people hear "endangered species", they think of animals.

7. Most people hear "endangered species", they think of animals.

8. Most people hear "endangered species", they think of animals.

(d3) Hiromi is difficult to learn mathematics.

1. ヒロミは数学のことを考えると気嚾しくなる.

2.ヒロミは数举を敬遠している.

3. ヒロミは数学とは馬が合わない。

4. ヒロミは数举が嫌いなわけじゃない.

5. $<>$ is difficult $<>$ to learn mathematics.

6. Hiromi is difficult to learn mathematics.

7. Hiromi is $<>$ difficult to learn mathematics.

8. Hiromi is difficult to leam mathematics. 
(e1) For badly wounded, the soldier stopped fighting.

1. 兵士はひどくけがをしなければ戦わなかった.

2. 兵士は戦うのをやめたとたんけがをしてしまった。

3. 兵土は重伤を負ったので戦いをやめた.

4. 重伤を負ってもなお, 兵士は戦わなかった.

- 5. Eor badly wounded, the soldier stopped fighting.

6. For badly wounded, the soldier stopped fighting.

7. For badly wounded, $<>$ the soldier stopped fighting.

8. For badly wounded, the soldier stopped fighting.

(92) It is my mother to like arranging little trees in the garden.

1. 庭木は母に世話をされるのが好きです.

2. 庭木の世話をするのはもっぱら母です。

3. 母は庭木の世話しか関心がありません。

4. 母の世話をするのは私たちのつとめです.

5. It is my mother to like arranging little trees in the garden.

6. It is $<>$ my mother to like arranging little trees in the garden.

- 7. It is my mother to like arranging little trees in the garden.

8. It is my mother to like arranging little trees in the garden.

(96) What I want is cup, not glass.

1. ほしいのはコッブじゃなくてグラスだぜ.

2. ほしいのはグラスじゃなくてコッブだぜ.

3. コッブもグラスもいらねえと五ってるんだ.

4. いくらコッブをほしがってもグラスは出て来やしない.

5. What I want is cup, not glass.

6. What I want $<>$ is cup, not glass.

- 7. What I want is $<>$ cup, not $<>$ glass.

8. What I want is cup, $<>$ not glass.

(97) When the magician appeared, Bill came downstairs to see the magician.

1. 奇術師が現れるのがわかっていたかのようにビルは下におりてきた.

2. 奇術師か現れる前からピルは下の階にいた。

3. 奇術師が現れるとビルは見にやってきた.

4. 奇術師が現れるとピルは別の奇術師だと思っておりてきた。

5. When the magician appeared, Bill came downstairs to see the magician.

6. When the magician appeared, Bill came downstairs to see the magician.

7. When the magician appeared, Bill came downstairs to see the magician.

- 8. When the magician appeared, Bill came downstairs to see the magician.

(g8) We did not know what to do with us.

1. 私たちが知っていたことを他の誰も知らなかった。

2. 私たちのほかに碓がいるのかわからなかった.

3. 私たち以外には鹳も私たちのことを知らなかった。

4. 私たちだけではどうしたらいいのかわからなかった.

5. We did not know what to do with us.

6. We did not know what to do with us.

7. We did not know what to do with us.

- 8. We did not know what to do with us.

(b4) Carl was upset last night because he had to do too many homeworks.

1. カールは㑑䁌は决して終わらないことがわかっていた.

2. カールは宿用がたくさんあったのでブリブリしていた.

3. カールは休んでいたので宿題がたまってしまった.

4. カールは山のような宿用に気が遠くなった.

5. Carl was upset last night because he had to do too many homeworks.

6. Carl was upset last night because he had to do too many homeworks.

7. Carl was upset last night because he had to do too many homeworks. 
- 8. Carl was upset last night because he had to do too many homeworks.

1. 試合を見たので選手のことがわかるようになった.

2. 選手のことを知っていたら武合はもっとおもしろかっただろうに.

3. 試合を見ても知っている選手のことしか眼中になかった.

4. 少しは選手を知っていたので武合を見た.

5 . I watched the match because I knew some of the playing people.

6. I watched the match because I knew some of the playing people.

7. I watched the match because I knew some of the playing people.

- 8. I watched the match because I knew some of the playing people.

\section{Grammar test - dichotomous [Version A only]}

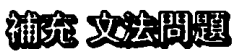

次のそれそれの文を院み，文法的に正しいと思うものには（）内に○を、哭っていると思うものには（ ）内にメ をつけてください, どうしても判断できないものは空橍のままで結輔です.

[Read each sentence. If you think it is grammatically correct, write "O" in the parentheses. If you think it is grammatically incorrect, write " $X$ " in the parentheses. If you cannot make a judgement, leave the space blank.]

In this test all the items except for $\boldsymbol{b} 7$ are incorrect.

( ) - You will find the glasses with red marks on both sides are quite expensive.

( ) 15 The Department of Foreign Languages are not located in the new building.

( ) T Take this flight which I think that is least expensive.

( ) Mr Kawase, vice president of Tomato Bank, he will speak to the press this afternoon.

( ) I I was having such a nice time I didn't want to leave.

( )...c Most people hear "endangered species", they think of animals.

( ) 10 Hiromi is difficult to learn mathematics.

( ) ..el For badly wounded, the soldier stopped fighting.

( ) ...\$2 It is my mother to like arranging little trees in the garden.

( ) ....66 What I want is cup, not glass.

( ) ....17 When the magician appeared, Bill came downstairs to see the magician.

( )...88 We did not know what to do with us.

( )...h4 Carl was upset last night because he had to do too many homeworks.

( )...n6 I watched the match because I knew some of the playing people.

\section{C-test}

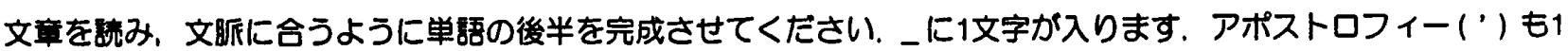
文字に数えます. わからないところがあっても文章の後の方にヒントが見つかるかも知れません.

[Read each text carefully. Complete the second half of the mutilated words so it will best fit the context. one underlined blank corresponds to one letter. An apostrophe should be counted as one letter. In some cases you may find the hint in the following context.]

In this list the correct answers are filled.

(Heart to Heart:57) Items $=29$

Yoshiko flew to L.A. to see her cousin. On

the airplane, she wanted to listen to music

to relax but found that her headget was

not working properly. No music came on. So 
she called a flight attendant and told him the problem. He miled and said, "Oh, yos느 can moye to any unoccupied sea t you'd like." He

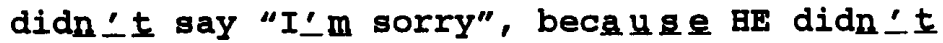
break the headset.

[2] (Reading Power:103) Items $=23$

Diamonds are very expensive for several reasons. First, they are difficuㅣㄴㅡ to find. They are only found in a fer places in the wor 1 d. Second, the $y$ are useful. People use diamonds to cut other stones. Third, diamonds do not change. They stay the same for milliong of yearng. And finally, they are very beautiful.

[3] (SRARate Builder 2B brown O) Items $=26$

Penguins are birds. They live where it's very cold. Most haye black and white featherg. The feathe포 are oily and keep the pengu ing dry and warm.

Pengying can't fly, but the $y$ can swim. And they stand on two little legs. They can't walk fast. They like to slide on the sno $w$ and icce. When they get tired, they stand still and sleep.

[4] (SRA2B blue 4) Items $=43$

Mr Glen was driving his car down a busy city street. There was a big van in front of him. Suddenly the van began to go faster. Its $\mathrm{g}$ back doon flew open, and out fell a big white pig! The poox pig landed on its back with its feet in the air. It just lay there.

"Oh, dear," Mr Glen said. "I hope it's not hurt."

Ee got out of his car and ran up to the pig.

"Are you all right?" he asked. The pig did not answer. Its eyen were cloged Mr Glen patted the pig on its fat tummy. In a minute the pig opened its eyes. 